Deliwe, M. \& Amabeoku, G.J. (2013). Evaluation of the antidiarrhoeal and antidiabetic activities of the leaf aqueous extract of Syzygium cordatum hoscht. ex C.Krauss (Mytraceae) in rodents. International Journal of Pharmacology, 9(2): 125 - 133

\title{
Evaluation of the antidiarrhoeal and antidiabetic activities of the leaf aqueous extract of Syzygium cordatum hoscht. ex C.Krauss (Mytraceae) in rodents
}

\author{
M. Deliwe and G.J. Amabeoku
}

\begin{abstract}
:
Syzygium cordatum Hoscht. ex C.Krauss is widely used by traditional medicine practitioners to treat many ailments including diarrhoea and diabetes. Despite the folklore use, little evidence can be found in literature to corroborate the claims of therapeutic success of the plant species. The objective of the study was to investigate the antidiarrhoeal and antidiabetic activities of the leaf aqueous extract of the plant species in mice and rats, respectively. The antidiarrhoeal activity of the leaf aqueous extract of S. cordatum was investigated using castor oil-induced diarrhoeal test. The antidiabetic activity of the plant extract was studied using streptozotoxin-induced diabetes in rats. Acute toxicity study of plant extract was also carried out using a standard method. Leaf aqueous extract of S. cordatum significantly reduced the number of diarrhoeal episodes, decreased the stool mass and delayed the onset of castor oil-induced diarrhoea in mice. Loperamide was shown to protect the animals against castor oil-induced diarrhoea. Both the leaf aqueous extract of S. cordatum and chlorpropamide significantly lowered the blood glucose levels in both normal and streptozotoxin-induced diabetic rats. The $\mathrm{LD}_{50}$ value obtained for the plant extract was over $4000 \mathrm{mg} \mathrm{kg-1}$ orally. The results obtained suggest that the leaf aqueous extract of S. cordatum has both antidiarrhoeal and antidiabetic activities. This justifies the folklore use of the plant species by traditional medicine practitioners to treat diarrhoea and diabetes. The relatively high LD50 value obtained for the leaf aqueous extract shows that the plant species is non toxic to mice.
\end{abstract}

\section{Introduction}

The use of medicinal plants in South Africa is an age long practice. Many people living, especially in rural communities, in the country depend on plant medicines for their healthcare needs. Syzygium cordatum Hoscht. ex C. Krauss is one of such plants used by traditional medicine practitioners in South Africa to treat various ailments (Van Wyk et al., 1997; Watt and Breyer-Brandwijk, 1962). S. cardatum (family, Myrtaceae) is a mediwn sized tree which can grow as tall as $15 \mathrm{~m}$ in height with bluish-green coloured broad leaves. It is widely distributed in the eastern and northeastern parts of South Africa and is known locally as "montlho" in Northern Sotho, "waterbessie" in 
Afrikaans and "wndoni" in both Xhosa and Zulu. It is known in English as water berry. All parts of the plant species including the leaves, bark and roots, have been shown to have medicinal properties. Infusion and decoctions of S. cordatum have been used by traditional medicine practitioners to treat diarrhoea, stomach aches, diabetes, respiratory problems and tuberculosis and have also been used to induce vomiting (Van Wyk et al., 1997; Hutchings, 1996; Watt and Breyer-Brandwijk, 1962). According to literature, some work has been done on the chemical constituents of S. cardatum. Candy et al. (1968) showed that the wood and bark of the plant species contain certain triterpenoids and various gallic acids (tannins). Chalannavir et al. (2011) and Chisowa et al. (1998) investigated the chemical constituents of the essential oil from the leaves of the plant species. However, little work has been done on the pharmacological actions of S. cordatum (Musabayane et al., 2005) to corroborate its therapeutic success in the treatment of various ailments as claimed by the traditional medicine practitioners. The main aim of this study was therefore, to investigate the antidiarrhoeal and antidiabetic activities of the leaf aqueous extract of S. cordatum. Phytochemical qualitative analysis, acute toxicity and HPLC studies of the plant species were also carried out.

\section{Materials and methods}

Plant materials: Fresh leaves of Syzygium cordatum were collected from Kirstenbosch National Botanical Gardens, Cape Town, South Africa in September 2009. The identification of the plant species was done by both the curator of the Gardens and M. Franz Weitz, a taxonomist in the Department of Biodiversity and Consenrative Biology, University of the Western Cape and a voucher specimen (SC8231) was deposited in the Herbarium of the University.

\section{Preparation of leaf aqueous extract of}

Syzygium cordatum: The fresh leaves of the plant species were weighed (1.4 kg), washed with distilled water and dried at $35^{\circ} \mathrm{C}$ for 4 days. The dried leaves $(857 \mathrm{~g})$ were ground to fine powder. Weighed quantity ( $80 \mathrm{~g}$ ) of the fine powder was refluxed in 11 of boiling water, allowed to cool and filtered. The filtrate was then frozen at- $80^{\circ} \mathrm{C}$ and freeze-dried for 5 days. A yield of $19.57 \mathrm{~g}$ of dried leaf aqueous extract was obtained and stored in a dessicator for future use. Fresh extract solutions were prepared every day of the experiment by dissolving weighed quantities of the extract in physiological saline. The solutions were administered orally to mice or rats in a volume of $1 \mathrm{~mL} 100 \mathrm{~g}$ of animal using bulbed steel needle.

Drugs and chemicals: Castor oil (GR Pharmaceuticals (Pty) Ltd, Atlantis, South Africa) was administered orally in a constant volwne to mice throughout the experiments using bulbed steel needle. Lopermaide ( 4[p-chlorophenyl] -4-hydroxy-N ,N -dimethyl-dipheny 11-piperidinebutyramine) hydrochloride (Sigma Chemical Co.,) was dissolved in a minimum amount of $10 \%$ ethanol (Merck (Pty) Ltd. and made up to the appropriate volume with physiological saline. Activated charcoal (Sigma Chemical Co.), an aqueous suspension of $5 \%$ charcoal and 5\% acacia, was prepared. Both the loperamide solution and the charcoal meal were given orally to mice in a volwne of $1 \mathrm{~mL} 100 \mathrm{~g}$ of animal using a bulbed steel needle. 
Streptozotocin (STZ, Sigma Chemical Co.) was dissolved in a small volume of o.1 M citrate buffer $\mathrm{pH} 4.5$, and made up to the appropriate volume with physiological saline, and administered intraperitoneally to rats in a volume of $1 \mathrm{~mL} 100 \mathrm{~g}$ animals. Chlorpropamide (Sigma Co.) was dissolved in physiological saline and administered orally to rats in a volume of $1 \mathrm{~mL} 100 \mathrm{~g}$ of animal using a bulbed steel needle.

Animals: Male albino mice bred in the Animal House of the Discipline of Pharmacology, University of the Western Cape, South Africa and weighing 18 - 30 g were used for the antidiarrhoeal activity and the acute toxicity testing of the plant species. Y otmg adult male Wis tar rats, bought from the University of Cape Town, South Africa and weighing 160-210 g were used for the antidiabetic activity. The animals were housed in a quiet laboratory with an ambient temperature of $20-24^{\circ} \mathrm{C}$ and a $12 \mathrm{~h} \mathrm{light} / 12$-h dark cycle was maintained. They were all maintained on a standard pellet diet and water ad libitum. All the animals were fasted for $16 \mathrm{~h}$ during which they had free access to water prior to the commencement of the experiments.

Phytochemical qualitative analysis: The methods of Ikhiri et al. (1992) and Harbome (1984) were used to analyse the dried powdered leaf of S. cordatum for various chemical compounds.

Assessment of antidiarrhoeal activity: Male albino mice, weighing between 18 and 30 $\mathrm{g}$, were used in groups of six per dose of plant extract or loperamide, a standard antidiarrhoeal drug, throughout the experiments after fasting for $16 \mathrm{~h}$. The method described by (Williamson et al., 1996a) was modified and used to assess the antidiarrhoeal activity of the plant extract. Castor oil, a laxative, known to cause diarrhoea within $4 \mathrm{~h}$, was used to induce diarrhoea in a control group of mice pre-treated with $0.3 \mathrm{~mL}$ (p.o.) of physiological saline for $15 \mathrm{~min}$ prior to the oral administration of $0.7 \mathrm{~mL}$ of castor oil. The onset of diarrhoea, the nwnber of diarrhoeal episodes, stool mass and the nwnber of mice exhibiting diarrhoea were obtained over a $5 \mathrm{~h}$ period of obsenration. Experiments were repeated with other groups of animals (test groups), pre-treated for $15 \mathrm{~min}$ with either leaf aqueous extract (3.125-50 mg kg-') of the plant species or the standard antidiarrhoeal drug, loperamide (20 $\mathrm{mg} \mathrm{kg-'),} \mathrm{both} \mathrm{given} \mathrm{orally} \mathrm{in} \mathrm{a} \mathrm{volwne} \mathrm{of} 1 \mathrm{~mL} 100 \mathrm{~g}$ of animals prior to the administration of $0.7 \mathrm{~mL}$ (p.o.) of castor oil. The ability of the plant extract to reduce the number of animals exhibiting diarrhoea and/or the number of diarrhoeal episodes is taken as an antidiarrhoeal activity (Williamson et al., l 996a). The doses and pretreatment times used were obtained from preliminary studies in the laboratory. All experiments were carried out between 08:00 hand $17: 00 \mathrm{~h}$ in a quiet laboratory with an ambient temperature of $20-24^{\circ} \mathrm{C}$.

Assessment of gastrointestinal propulsion of charcoal meal: The methods used to assess the effect of the plant extract on the gastrointestinal transit of charcoal meal were those described by Williamson et al. (1996a) and Kitano et al. (1994). Animals were used in groups of six per dose ofleaf aqueous plant extract (3.125-50 mg kg-', p.o.) or loperamide (20 mg kg-', p.o.), a standard antidiarrhoeal drug, after fasting for $16 \mathrm{~h}$. Control group was pretreated with $0.3 \mathrm{~mL}$ of physiological saline given orally, for $20 \mathrm{~min}$ and 
then given $0.4 \mathrm{~mL}$ of charcoal meal (aqueous suspension of $5 \%$ charcoal and $5 \%$ gwn acacia) orally. The animals were then killed by ether inhalation 20 min after the administration of charcoal meal and the intestine was removed from the cardia to the rectal end. The distance travelled by the charcoal meal was measured and expressed as a percentage of the total length of the intestine. Experiments were repeated with other groups of animals (test groups) pretreated with the leaf aqueous plant extract (3.125-50 mg kg-') or loperamide (20 mg kg-'), both given orally in a volume of $1 \mathrm{~mL}$ $100 \mathrm{~g}$ of animals, prior to the administration of $0.4 \mathrm{~mL}$ of charcoal meal. All experiments were carried out between 08 : $00 \mathrm{~h}$ and 17:00 $\mathrm{h}$ in a quiet laboratory with an ambient temperature of $20-24^{\circ} \mathrm{C}$.

Assessment of castor oil-induced intestinal fluid accumulation: The methods of Robert et al. (1976) and Di Carlo et al. (1994) were modified and used to assess the effect of the plant extract on castor oil-induced intestinal fluid accumulation. The animals were used in groups of six per dose ofleaf aqueous plant extract $(3.125-50 \mathrm{mg}$ kg-', p.o.) or loperamide (20 mg kg-', p.o.), a standard antidiarrhoeal drug, after fasting for 16 hours. The control group of six mice was pretreated with $0.3 \mathrm{~mL}$ (p.o.) of physiological saline for $15 \mathrm{~min}$ and then given $1.5 \mathrm{~mL}$ of castor oil orally. The animals were then killed by ether inhalation 20 minutes after the administration of castor oil and the intestines removed from the pylorus to the caecwn. The intestinal contents were then evacuated into a measuring cylinder and the volume measured. Experiments were repeated with other groups of animals pretreated for $15 \mathrm{~min}$ with the leaf aqueous plant extract (3.125-50 mg kg-') or loperamide (20 mg kg-'), a standard antidiarrhoeal drug, both given orally in a volwne of $1 \mathrm{~mL} 100 \mathrm{~g}$ of animals, prior to the oral administration of $1.5 \mathrm{~mL}$ of castor oil. All experiments were carried out between $08: 00 \mathrm{~h}$ and 17:00 $\mathrm{h}$ in a quiet laboratory with an ambient temperature of $20-24^{\circ} \mathrm{C}$.

Assessment of antidiabetic activity: Modified methods of Williamson et al. (1996b) and Joy and Kuttan (1999) were used to assess the antidiabetic activity of the leaf aqueous extract of Syzygium cordatum. Rats in groups of six each were divided into normoglycaemic and diabetic rats. The normoglycaemic rats were further divided into 'control and test' groups. The control group of six rats received $0.3 \mathrm{~mL}$ of physiological saline orally while five groups (of six rats each) of test rats were treated with the leaf aqueous extract of Syzygium cordatum (3.125-50 mg kg-', p.o.). One group of six test rats received chlorpropamide (250 $\mathrm{mg} \mathrm{kg}-\mathrm{-}^{\prime}$, p.o.), a standard antidiabetic drug.

Similarly, the diabetic rats were divided further into 'control and test' groups. Diabetes was induced in all the diabetic rats by intraperitoneal injections of streptozotocin (STZ, $90 \mathrm{mg} \mathrm{kg-').} \mathrm{Following} \mathrm{the} \mathrm{injection,} \mathrm{diabetes} \mathrm{was} \mathrm{allowed} \mathrm{to}$ develop and stabilize in the rats over a period of 3-5 days. The diabetic control group received $0.3 \mathrm{~mL}$ of physiological saline orally. Five groups of test diabetic rats received the leaf aqueous extract of the plant species $(3.125-50 \mathrm{mg} \mathrm{kg-'}$,

\section{http://repository.uwc.ac.za}


p.o.) whereas one group of test diabetic rats received chlorpropamide (250 mg kg-', p.o.). In both normoglycaemic and diabetic rats, blood glucose levels were measured first without treatment $(\mathrm{oh})$ and then, the animals received either $0.3 \mathrm{~mL}$ (p.o.) of physiological saline, plant extract (3.125-50 mg kg-', p.o.) or chlorpropamide (250 mg kg-', p.o.) after which the blood glucose levels were measured at intenrals of $1 \mathrm{~h}, 2 \mathrm{~h}$ and $4 \mathrm{~h}$ in each treatment group. The blood samples for the measurement of the glucose levels were obtained by pricking the rat tail tip vein. A drop of blood was placed on a glucose test strip and the glucose level read using a compatible Glucometer (Accu-Check Abbot laboratory). Blood was obtained from both normoglycaemic and diabetic rats before treatment (o h) and then 1, 2 and $4 \mathrm{~h}$ after treatment with physiological saline, plant extract or chlorpropamide. Each glucose test strip was used only for one reading. Fasted streptozotocin-treated rats with blood glucose level greater than or equal to $18 \mathrm{mmol} \mathrm{L}-1$ were considered diabetic. The ability of the plant extract to significantly lower the blood glucose level below $18 \mathrm{mmol} \mathrm{L-1} \mathrm{is} \mathrm{taken} \mathrm{as} \mathrm{an} \mathrm{antidiabetic} \mathrm{activity} \mathrm{(Williamson} \mathrm{et} \mathrm{al.,} \mathrm{l}$ 996b; Joy and Kuttan, 1999).

Acute toxicity testing: Male albino mice were used in groups of six per dose of plant extract after fasting for $16 \mathrm{~h}$. The method of Lorke (1983) was modified and used to assess the acute toxicity of the leaf aqueous extract of Syzygium cordatum. The plant extract was administered orally to mice in graded doses (200, 400, 800, 1200, 1600 , 2000, 2400, 2800, 3200, 3600 and $4000 \mathrm{mg} \mathrm{kg-').} \mathrm{Another} \mathrm{group} \mathrm{of} \mathrm{six} \mathrm{mice}$ used as control, received $0.3 \mathrm{~mL}$ physiological saline orally. Both the test and control animals were then allowed access to food and water and obsenred over a period of 5 days for any deaths or acute toxicity symptoms such as hypoactivity, piloerection, salivation and so on. The log dose/response (\% death) cunre plot is used to calculate the median lethal dose (LDoc) (Amabeoku and Kinyua, 2010). Since no death occurred in all the doses of $R$. raveolens administered, the $\mathrm{LD}_{50}$ of the plant species was estimated from the data obtained.

\section{HPLC analysis}

Chromatographic system: Beckman HPLC system consisting of double pump Programmable Solvent Module model 126; Diode Array detector Module model 168; Samstmg computer 386 with management System Gold (Gold V601) software supplied by Beckman; Column, Cl 8 Bondapak $5 \mu \mathrm{m}$ and dimensions (250x $4.6 \mathrm{~mm}$ ).

Chromatographic conditions: Mobile phase: solvent A: $1 \%$ acetic acid, solvent B; methanol, Mode: gradient, flow rate, $1 \mathrm{~min} / \mathrm{min}$, injection volume: $10 \mu \mathrm{L}$, detector: $1 \mathrm{~N}$ at $350 \mathrm{~nm}$, The HPLC operating conditions were programmed to give the following: $O$ min, solvent B: $20 \%$; 5 min, solvent B: $40 \%, 15 \mathrm{~min}$, solvent B: $60 \%, 20 \mathrm{~min}$, solvent B: $80 \%$ and $27 \mathrm{~min}$, solvent $\mathrm{B}: 20 \%$. The run rate was $30 \mathrm{~min}$. 
Statistical analysis: The data obtained from the antidiarrhoeal, antipropulsive or antidiabetic activity and intestinal fluid accwnulation experiments were analysed using one-way analysis of variance (ANOVA) followed by Dunnett's multiple comparison (GraphPad Prism, version 5.0, GraphPad Software, Inc., San Diego CA 92130, USA) and presented as mean \pm Standard Error Mean (SEM). However, the data on the number of animals exhibiting diarrhoea were analysed using the Chi square test. In the above cases, $\mathrm{p}$-values of less than $5 \%(\mathrm{p}<0.05), 10$ were considered to be significant.

Ethics clearance: The Ethics Committee of the University of the Western Cape approved the experimental protocol $(07 / 04 / 31)$ used in the present study and this conforms to the "Guide to the care and use of animals in research and teaching" of the University.

\section{Results}

Effect of leaf aqueous extract of $S y$ zygium cordatum on castor-oil induced diarrhoea: Castor-oil $(0.7 \mathrm{~mL})$ given orally, produced diarrhoea within 4 $\mathrm{h}$ in all the six animals used and also produced a considerable amount of stool. Syzygium cordatum (3.125-50 mg kg-', p.o.) significantly reduced the faecal output produced by castor oil. S. cordatum in all the doses used, reduced the faecal output from $100 \%$ produced by castor-oil to between 40 and $61 \%$. S. cordatum (6.25-50 mg kg-', p.o.) significantly and in a dose dependent manner, delayed the onset of castor oil (0.7 mL, p.o)-induced diarrhoea. Doses of 3.125-50 mg kg-' (p.o.) significantly reduced castor oil ( $0.7 \mathrm{~mL}$, p.o.)-induced diarrhoeal episodes but did not significantly alter the nwnber of animals exhibiting diarrhoea. Loperarnide (20 mg kg-', p.o.) significantly reduced the faecal output produced by castor-oil ( $0.7 \mathrm{~mL}$, p.o.) from $100 \%$ produced by castor oil to $8.7 \%$. The dose of $20 \mathrm{mg} \mathrm{kg-'} \mathrm{(p.o.)} \mathrm{of} \mathrm{loperarnide} \mathrm{profoundly} \mathrm{delayed} \mathrm{the} \mathrm{onset} \mathrm{of} \mathrm{diarrhoea}$ produced by castor-oil (0.7 mL, p.o.) and profoundly reduced the incidence of castor-oil (0.7 mL, p.o.)-induced diarrhoea by protecting $83 \%$ of animals against the diarrhoea. Loperamide (20 $\mathrm{mg} \mathrm{kg-}^{1}$, p.o.) profoundly reduced the nwnber of castor-oil (0.7 mL, p.o.)-induced diarrhoeal episodes by $96 \%$ (Table !).

\section{Effect of leaf aqueous extract of $S y$ zygium cordatum on gastrointestinal} transit of charcoal meal: The mean length of intestine travelled by $0.4 \mathrm{~mL}$ (p.o.) of charcoal meal in control mice pretreated with $0.3 \mathrm{~mL}$ (p.o.) of physiological saline was $87.73 \pm 5.01 \%$. Leaf aqueous extract of Syzygium cordatum (6.25-50 mg kg-', p.o.) significantly and dose dependently decreased the mean length of intestine travelled by $0.4 \mathrm{~mL}$ (p.o) of charcoal mean. The propulsion of the charcoal mean was inhibited by 21.25-50.93\% at doses of $3.125-50 \mathrm{mg} \mathrm{kg-'}$ (p.o.) of S. cordatum. Loperarnide (20 mg kg-', p.o.) significantly reduced the mean length of intestine travelled by charcoal meal (0.4 rnL, p.o. ). Loperamide (20 mg kg-', p.o.) inhibited the propulsion of charcoal meal by $79.06 \%$ (Table 2 ). 


\begin{tabular}{|c|c|c|c|c|c|c|}
\hline $\begin{array}{l}\text { Treatment groups } \\
\left.\text { (mg kg }{ }^{-1}\right)\end{array}$ & $\begin{array}{l}\text { Mass of stool (g) } \\
\text { (Mean+SEM) }\end{array}$ & $\begin{array}{l}\text { Faecal } \\
\text { output }(\%)\end{array}$ & $\begin{array}{l}\text { Onset of diarrhoea (min) } \\
\text { (Mean } \pm \text { SEM) }\end{array}$ & $\begin{array}{l}\text { No. of diarrhoeal episode } \\
\text { (Mean } \pm \text { SEM) }\end{array}$ & $\begin{array}{l}\text { Percentage diarthoeal } \\
\text { episode inhibition }(\%)\end{array}$ & $\begin{array}{l}\text { No. of animals } \\
\text { exhibiting diarrhoea }\end{array}$ \\
\hline \multicolumn{7}{|c|}{ C } \\
\hline $0.3 \mathrm{~mL}$ & $3.67 \pm 0.29$ & 100.0 & $22.17 \pm 2.10$ & $25.17 \pm 0.93$ & & $6 / 6$ \\
\hline 3.125 & $2.22 \pm 0.14^{\text {\#标 }}$ & 60.5 & $42.17 \pm 3.90$ & $10.83 \pm 1.49^{\text {我吸 }}$ & 56.97 & $6 / 6$ \\
\hline 6.25 & $2.22 \pm 0.39^{* *}$ & 60.5 & $70.83 \pm 5.67^{k}$ & $12.17 \pm 2.40^{\text {**in }}$ & 51.65 & $6 / 6$ \\
\hline 12.50 & $1.80 \pm 0.27^{4130}$ & 49.0 & $71.50 \pm 4.32^{4}$ & $8.00 \pm 1.05^{* * 1: 3}$ & 68.22 & $6 / 6$ \\
\hline 25.00 & $1.45 \pm 0.28^{* 3 *}$ & 39.5 & $79.33 \pm 5.97^{k}$ & $5.67 \pm 1.30^{\text {**as }}$ & 77.47 & $6 / 6$ \\
\hline 50.00 & 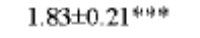 & 49.9 & $105.17 \pm 19.60^{\text {tsin }}$ & $9.83 \pm 0.96^{\text {*414 }}$ & 60.95 & $6 / 6$ \\
\hline \multicolumn{7}{|l|}{ Loperamide } \\
\hline 20.00 & $0.32 \pm 0.18^{\text {knth }}$ & 8.7 & $119.83 \pm 16.57^{\text {kwin }}$ & $1.00 \pm 0.00^{\text {tanis }}$ & 96.02 & $1 / 6^{+}$ \\
\hline
\end{tabular}

\section{Effect of leaf aqueous extract of $S y$ zygium cordatum on castor oil-induced} intestinal fluid accumulation: The mean intestinal fluid volwne produced by castor oil (1.5 mL, p.o.) in control animals pretreated with physiological saline (0.3 $\mathrm{mL}$, p.o.) was $1.42 \pm 0.19 \mathrm{~mL}$. Syzygium cordatum (3.125-50 mg kg-', p.o.) significantly reduced the mean intestinal fluid volwne produced by castor oil (1.5 rnL, p.o.). The mean intestinal fluid volume was reduced or inhibited by $41.55-59.15 \%$. Loperaruide (20 mg kg-1, p.o.) significantly reduced the mean intestinal fluid volume produced by castor oil (1.5 mL, p.o.). The mean intestinal fluid volume produced by castor oil (1.5 mL, p.o.) was inhibited by loperarnide (20 mg kg-', p.o.) by $52.82 \%$ (Table 3).

\section{Effect of leaf aqueous extract of $S y$ zygium cordatum on blood glucose} concentrations (mmol L-1 ${ }^{1}$ of normoglycaemic rats: Physiological saline (0.3 Ll, p.o.) did not significantly alter the blood glucose concentration of fasted normal rats throughout the $4 \mathrm{~h}$ period of observation. Syzygium cordatum (3.125-6.25 $\mathrm{mg}$ kg-', p.o.) did not significantly affect the blood glucose concentration of fasted normal rats throughout the $4 \mathrm{~h}$ of observation. Doses of 12.50-50 mg kg-' (p.o.) of Syzygium cordatum significantly reduced the blood glucose concentration of fasted normal rats from the second to the fowth hour of obsenration with a percentage maximal reduction of $28.60-32.79 \%$. Chlorproparnide ( $250 \mathrm{mg} \mathrm{kg-'}$, p.o.) significantly reduced the blood glucose concentration of fasted normal rats from the first hour through to the fowth hour of obsenration and the percentage maximal reduction was $43.26 \%$ (Table 4).

Table 2: Effect of leaf aqueous extract of Syzugium cordaum on gastrointestinal transit of charcoal meal in mice

\begin{tabular}{|c|c|c|}
\hline Treatment groups ( $\mathrm{mg} \mathrm{kg}^{-1}$ ) & Length of intestine travelled $(\%)$ Mean $\pm S E M$ & Percentage inhibition in length of intestine travelled $(\%)$ \\
\hline \multicolumn{3}{|l|}{ PS } \\
\hline $0.3 \mathrm{~mL}$ & $87.73 \pm 5.01$ & \\
\hline \multicolumn{3}{|l|}{ Syygiumecordatum } \\
\hline 3.125 & $69.09 \pm 4.87$ & 21.25 \\
\hline 6.25 & $63.17 \pm 4.57^{*}$ & 28.00 \\
\hline 12.50 & $62.34 \pm 7.20^{4}$ & 28.94 \\
\hline 25.00 & $58.48 \pm 5.95^{\text {水 }}$ & 33.34 \\
\hline 50.00 & $43.05 \pm 9.84 * * *$ & 50.93 \\
\hline \multicolumn{3}{|l|}{ Loperamide } \\
\hline 20.00 & 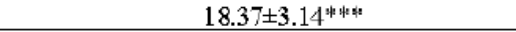 & 79.06 \\
\hline
\end{tabular}

${ }^{*} \mathrm{p}<0.05, * * \mathrm{p}<0.005, * * * \mathrm{p}<0.001$ vs. charcoal meal (0.4 mL, p.o.) control. ANOVA $(\mathrm{n}=6)$, PS: Physiological saline, \%: Percentage 
Table 3: Effect of leaf aqueous extract of Syzygiun cordasion on castor-oil induced intestinal fluid accumulation in mice Treatment groups ( $\mathrm{mg} \mathrm{kg}^{-1}$ ) Intestinal fluid volume $(\mathrm{mL})(\mathrm{Mean} \pm \mathrm{SEM})$

Percentage inhibition (\%)

PS

$0.3 \mathrm{~mL}$

Syzygium cordatum

3.125

6.25

12.50

25.00

50.00

Loperamide

20.00

*p<0.01, "p<0.001 vs. castor oil (1.5 mL, p.o.) control. ANOVA ( $n=6)$. PS: Ptrysiological saline, \%: Percentage
$1.42 \pm 0.19$

$0.58 \pm 0.04^{* * * 15} \quad 59.15$

$0.83 \pm 0.15^{*} \quad 41.55$

$0.80 \pm 0.02^{*}$

$0.80 \pm 0.05^{*} \quad 43.66$

$0.73 \pm 0.05^{*} \quad 48.59$

Table 4: Effect of leaf aqueous extract of Syzyginun cordamun on blood glucose concentrations of normogly caemic (normal) rats

\begin{tabular}{|c|c|c|c|c|c|c|}
\hline \multirow{3}{*}{$\begin{array}{l}\text { Treatment groups } \\
\left(\mathrm{mg} \mathrm{kg}^{-1}\right)\end{array}$} & \multicolumn{6}{|c|}{ Glucose concentration (mmol L-1) } \\
\hline & \multirow{2}{*}{$\begin{array}{l}\text { Before treatment } \\
0 \mathrm{~h}\end{array}$} & \multicolumn{3}{|c|}{ After treatment } & \multirow[b]{2}{*}{ Maximal reduction } & \multirow[b]{2}{*}{ Percentage maximal reduction $(\%)$} \\
\hline & & $1 \mathrm{~h}$ & $2 \mathrm{~h}$ & $4 \mathrm{~h}$ & & \\
\hline \multicolumn{7}{|l|}{ PS } \\
\hline \multicolumn{7}{|l|}{ Syzygium cordatum } \\
\hline 3.125 & $6.67 \pm 0.21$ & $5.90 \pm 0.13$ & $5.57 \pm 0.14$ & $5.72 \pm 0.27$ & 1.10 & 16.49 \\
\hline 6.25 & $6.75 \pm 0.25$ & $6.03 \pm 0.21$ & $5.37 \pm 0.18$ & $5.80 \pm 0.24$ & 1.38 & 20.44 \\
\hline 12.50 & $6.33 \pm 0.56$ & $5.98 \pm 0.22$ & $4.73 \pm 0.32^{*}$ & $4.52 \pm 0.38^{* 18}$ & 1.81 & 28.60 \\
\hline 25.00 & $6.80 \pm 0.20$ & $5.92 \pm 0.32$ & $4.75 \pm 0.15^{*}$ & $4.60 \pm 0.20 * *$ & 2.20 & 32.35 \\
\hline 50.00 & $6.80 \pm 0.29$ & $5.58 \pm 0.29$ & $4.62 \pm 0.12^{*}$ & $4.57 \pm 0.42^{* *}$ & 2.23 & 32.79 \\
\hline \multicolumn{7}{|l|}{ Chlorpropamide } \\
\hline 250 & $6.75 \pm 0.40$ & $4.85 \pm 0.29^{*}$ & 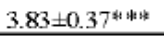 & 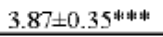 & 2.92 & 43.26 \\
\hline
\end{tabular}

${ }^{*} p<0.05,{ }^{* *} p<0.01,{ }^{* * *} \mathrm{p}<0.001$ vs. physiological saline $(0.3 \mathrm{~mL}, \mathrm{p} .0$.) control, ANOVA ( $=6$ ), Values are expressed as Mean \pm SEM, PS: Physiological saline, \%: Percentage

Table 5: Effect of leaf aqueous extract of Svzygium cordatum on blood glucose concentrations of streptozotocin-treated diabetic rats

\begin{tabular}{|c|c|c|c|c|c|c|}
\hline \multirow[b]{3}{*}{$\begin{array}{l}\text { Treatment groups } \\
\text { (mg kg-1) }\end{array}$} & \multicolumn{6}{|c|}{ Blood glucose concentration (mmol L ${ }^{-1}$ ) } \\
\hline & \multirow{2}{*}{$\begin{array}{l}\text { Before treatment } \\
0 \mathrm{~h}\end{array}$} & \multicolumn{5}{|c|}{ After treatment } \\
\hline & & $1 \mathrm{~h}$ & $2 \mathrm{~h}$ & $4 \mathrm{~h}$ & Maximal reduction & Percentage maximal reduction $(\%)$ \\
\hline \multicolumn{7}{|r|}{ 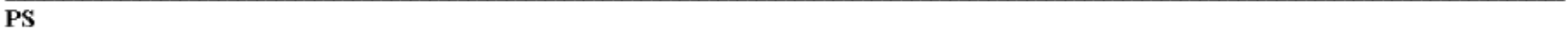 } \\
\hline \multicolumn{6}{|l|}{ Syzvoium cordatum } & \\
\hline 3.125 & $23.37 \pm 1.10$ & $23.78 \pm 0.66$ & $23.20 \pm 0.60$ & $22.95 \pm 0.47$ & 0.83 & 3.49 \\
\hline 6.25 & $22.68 \pm 1.04$ & $22.43 \pm 0.52$ & $20.77 \pm 0.55$ & $17.38 \pm 1.11^{*}$ & 5.30 & 23.37 \\
\hline 12.50 & $20.32 \pm 0.59$ & $21.28 \pm 1.14$ & $15.25 \pm 0.78^{*}$ & $14.22 \pm 1.80^{*}$ & 7.06 & 33.18 \\
\hline 25.00 & $20.17 \pm 0.57$ & $21.41 \pm 1.53$ & $14.12 \pm 0.12^{*}$ & $13.80 \pm 0.93^{*}$ & 7.61 & 35.54 \\
\hline 50.00 & $20.53 \pm 2.08$ & $14.42 \pm 0.87^{*}$ & $14.07 \pm 0.68^{*}$ & $13.68 \pm 0.89^{*}$ & 6.85 & 33.37 \\
\hline \multicolumn{7}{|l|}{ Chlorpropamide } \\
\hline 250 & $23.23 \pm 0.94$ & $15.55 \pm 1.34^{*}$ & $6.38 \pm 1.12^{*}$ & $4.05 \pm 0.24^{*}$ & 19.18 & 93.42 \\
\hline
\end{tabular}

${ }^{*} \mathrm{p}<0.001$ vs streptozotocin $\left(90 \mathrm{mg} \mathrm{kg}{ }^{-1}\right.$, i.p.) control, ANOVA $(\mathrm{n}=6)$, Values are expressed as Mean \pm SEM, PS: Physiological saline, \%: Percentage

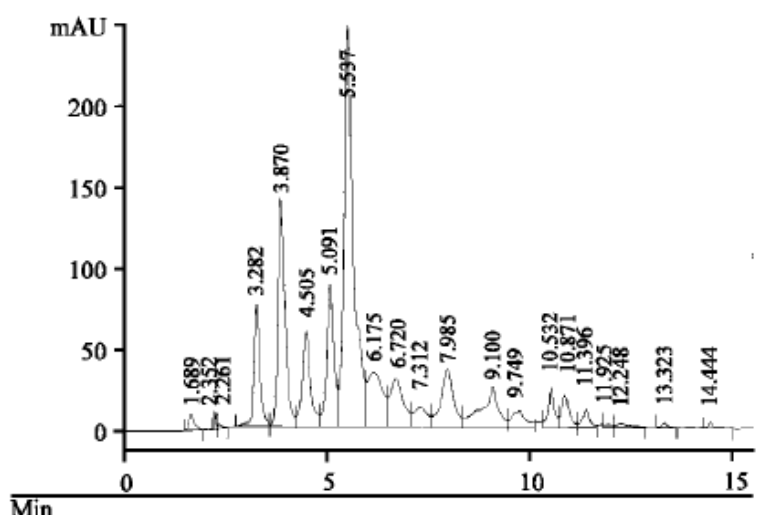

Fig. 1: Chromatographic fingerprint of Syzygium cordatum 
Effect of leaf aqueous extract of Syzygium cordatum on blood glucose concentrations (mmol L-1 ${ }^{1}$ of streptozotocin-treated diabetic rats: Streptozotocin (90 mg, p.o.) raised the blood glucose concentration of fasted animals to $21.40 \pm 1.02 \mathrm{mmol}$ $\mathrm{L}^{-1}$. Physiological saline (0.3 mL, p.o.) did not significantly affect the blood glucose concentration of fasted diabetic rats throughout the $4 \mathrm{~h}$ of observation. Dose of $3.125 \mathrm{mg}$ (p.o.) of Syzygium cordatum did not significantly alter the blood glucose concentration of the fasted diabetic rats throughout the $4 \mathrm{~h}$ of observation. Syzygium cordatum (6.25 mg kg-1 p.o.) significantly reduced the blood glucose of the fasted diabetic rats in the 4 th $h$ of observation with a maximal reduction of $23.37 \%$. Syzygium cordatum (12.50$25 \mathrm{mg}$, p.o.) significantly reduced the blood concentration of fasted diabetic rats from the 2nd to the 4 th $h$ of observation with a percentage maximal reduction of $33.18-35.54 \%$. At a dose of $50 \mathrm{mg} \mathrm{kg-1}$ (p.o.), S. cordatum significantly reduced the blood glucose concentration of fasted diabetic rats from the 1 st $\mathrm{h}$ through to the 4 th $\mathrm{h}$ of observation with a percentage maximal reduction of $33.37 \%$. Chlorpropamide (250 $\mathrm{mg} \mathrm{kg-}^{1}$, p.o.) profoundly reduced the blood glucose concentration of fasted diabetic rats from the 1st hour through to the 4th hour of observation with a percentage maximal reduction of $93.42 \%$ (Table Acute toxicity test: The leaf aqueous extract of Syzygium cordatum (200, 400, $800,1200,1600,2000,2400,2800,3200,3600$ and $4000 \mathrm{mg} \mathrm{kg}^{1} \mathrm{administered} \mathrm{orally}$ to mice did not cause any death to or any acute toxicity symptoms in the animals in all the doses used. The highest dose tested being $4000 \mathrm{mg} \mathrm{kg}^{-1}$ should be the NO-AdverseEffect-Level (NOAEL ). The $\mathrm{LD}_{50}$ value for the plant species may, therefore, be greater than $4000 \mathrm{mg} \mathrm{kg-}^{-1}$ (p.o.).

Phytochemical analysis: The phytochemical qualitative of the analysis of the plant species showed the presence of tannins, saponins, alkaloids, flavonoids, triterpene steroids and reducing sugars.

HPLC analysis: The chromatographic fingerprint of the leaf methanol extract of $S$. cordatum showed major peaks at the following retention times (minutes): $3.282,3.870$, 5.537 and 7.985 (Fig. 1)

\section{Discussion}

In this study, the plant extract, up to the highest dose (4000 mg kg-1, p.o.) used in the acute toxicity test, did not cause any death to or acute toxicity symptoms in the mice. The $\mathrm{LD}_{50}$, therefore, may be greater than $4000 \mathrm{mg}$ kg- ${ }^{1}$ (p.o.). This relatively high $\mathrm{LD}_{50}$ shows that the plant extract is non-toxic and/or safe in mice. Traditional medicine practitioners are known to use the plant for treatment in the form of infusion (Van Wyk et al., 1997). The HPLC chromatogram of $S$. cordatum showed characteristic peaks at a wavelength of $350 \mathrm{~nm}$. The pharmacological screening results obtained in the present study, show that $S$. cordatum (3.125-50 mg kg- 1, p.o.) antagonized the diarrhoea 
produced by castor oil (0.7 mL, p.o.). Loperamide (20 mg kg-1 p.o.) also antagonized the castor oil-induced diarrhoea in mice. Castor oil, an irritant laxative, is thought to produce diarrhoea by being hydrolysed in the upper small intestine to ricinoleic acid which exerts its effects by irritating the mucosa of the gastrointestinal tract, resulting in an increase in intestinal motility (Altman, 2001 ). Fwthermore, ricinoleic acid has been shown to diminish the permeability of sodiun and chloride ions and also stimulate the release of prostaglandin, known to cause diarrhoea (Tunaru et al., 2012; Zavala et al., 1998). In addition, the works of Capasso et al. (1994) and Mascolo et al. (1994), on the effect of NG-nitro-L-arginine methyl ester, an inhibitor of Nitric Oxide (NO) synthase, on the dissociation of castor oil-induced diarrhoea and mucosal injwy inrat, showed that nitric oxide may mediate castor oil-induced diarrhoea. Loperamide, an opioid derivative and a standard antidiarrhoeal drug, is thought to decrease intestinal motility by binding to mu receptors on neurons in the submucosal neural plexus of the intestinal wall. This leads to the segmental contractions in the colon increasing, the propulsive movement of the small intestine and colon being inhibited and the transit time of the intestinal content being prolonged (Altman, 2001). Loperamide 1s also known to have an antimuscarinic activity contributing to the inhibition of peristalsis by inhibiting contractions in both the longitudinal and circular muscles (Waller et al., 2005a; Camillen et al., 2002; Altman, 2001). In this study, therefore, loperamide may be antagonizing castor oil- induced diarrhoea by decreasing the intestinal motility. Similarly, Syzygium cordatum may be said to exert its antidiarrhoeal activity by slowing intestinal motility.

In the present study, the leaf aqueous extract of S. cordatum significantly antagonized the gastrointestinal transit of charcoal meal and also significantly reduced the castor oil-induced intraluminal accumulation of fluid volume. Similarly, loperamide significantly antagonized the gastrointestinal transit of charcoal meal and also significantly reduced the castor oil-induced intraluminal accumulation of fluid volume. According to Di Carlo et al. (1994), agents that reduce intestinal motility and secretion may possess antidiarrhoeal activity. Fwthermore, Nwafor et al. (2000) have shown that agents that suppress intestinal fluid accwnulation may inhibit gastrointestinal functions. The above reports lend support to the suggestion that S. cordatum may be exerting its antidiarrhoeal activity by slowing intestinal motility. It is also pertinent to state that the data obtained on the antidiarrhoeal activity of S. cordatum is in agreement with that of Sibandze et al. (2010) who reported the antidiarrhoeal properties of Breonadia salicina, Syzygium cordatum and Ozoroa sphaerocarpa against a diarrhoea-causing pathogen, Escherichia coli. Candy et al. (1968) in their study have shown that S. cordatum contain certain triterpenoids and various gallic acids (tannins). The qualitative phytochemical analysis of the powdered leaf of S. cordatum carried out in this study showed that the plant species contains tannins, saporuns, alkaloids, triterpene steroids, flavonoids and reducing sugars. Several studies have shown tannins to have antidiarrhoeal activity. Tannin containing drugs have been used for the treatment of diarrhoea and other related disorders (Bruneton, 1999; Frei et al., 1998). Astringents 
such as tannins have been known since the last centrny to have antisecretory effect in the gastrointestinal tract and have been used to treat diarrhoea (Farthing, 2000). It is probable therefore, that the presence of tannins in the plant species as shown by Candy et al. (1968) and the present study, may contribute to the antidiarrhoeal activity of S. cordatum.

Syzygium cordatum has been shown in the present study to have an antidiabetic activity. Chlorpropamide, a sulphonylurea, and an oral antidiabetic agent used for the treatment of Type 2 or Non-insulin Dependent Diabetes (NIDD), was used as a standard drug in this study. It is thought to act by stimulating and increasing the release of endogenous insulin from the pancreatic beta cells of the Islet of Langerhans (Rang et al., 2008; Waller et al., 2005b). Streptozotocin (STZ) used to induce diabetes in this study, on the other hand, is thought to produce diabetes by a rapid depletion of pancreatic beta cells and thereby, reducing insulin release and causing hyperglycaemia (Mahomed and Ojewole, 2003). Thus, the STZ-induced rat diabetes model has the halhnark of non- insulin dependent diabetes or Type 2 diabetes. In this study, S. cordatum (12.5-50 mg kg-', p.o.) and chlorpropamide (250 mg kg-', p.o.) siginficantly reduced the blood glucose concentration of fasted normal rats while $0.3 \mathrm{rnL}$ (p.o.) of physiological saline did not alter the blood glucose concentration of the fasted normal rats. Similarly, both the leaf aqueous extract of S. cordatum (12.5-50 mg kg-', p.o.) and chlorpropamide (250 mg kg-', p.o.) significantly reduced the glucose concentration of diabetic rats treated with streptozotocin. Since chlorpropamide used to treat diabetes, acts by stimulating insulin secretion from pancreatic beta cells and also promoting peripheral glucose uptake and utilization (Rang et al., 2008; Waller et al., $2005 \mathrm{~b}$ ), it is probable that $\mathrm{S}$. cordatum, may be acting in a similar manner. The result obtained in this study is in agreement with the study of Musabayane et al. (2005) who showed that S. cordatum leaf extract significantly lowered the plasma glucose and hepatic glycogen levels in STZ-induced diabetic rats.

In this study, the phytochemical analysis carried out revealed the presence of alkaloids and flavonoids amongst other chemical metabolites in S. cordatum. Punitha et al. (2005) in their study on berberine, an alkaloid, and antidiabetic activity, showed that alkaloids have antidiabetic activity. Dineshkwnar et al. (2010) in their study on the antidiabetic and hypolipidemic effects of mahanimbin from Murraya koenigii leaves also showed that alkaloids have antidiabetic activity. Flavonoids have also been shown by the study of Fawzy et al. (2008) which investigated the antidiabetic and antioxidant activities of major flavonoids of Cynanchum acutum L., to have antidiabetic activity. Furthermore, Hule et al. (2011) in their study on the evaluation of the antidiabetic effects of Elaeocarpus ganitrus in experimental animals, showed that alkaloids and flavonoids have antidiabetic activities. It is probable therefore, that the flavonoids and alkaloids found in S. cordatum may be contributing to its antidiabetic activity. 


\section{Conclusion}

The data obtained in this study indicated that Syzygium cordatum have both antidiarrhoeal and antidiabetic activities. This project was not set out to investigate the mechanisms of the antidiarrhoeal and antidiabetic activities of S. cordatum. However, various studies as indicated above have shown that castor oil- induced diarrhoea may also involve increase in electrolyte permeability, increased release of prostaglandins and nitric acid mechanism. It is probable therefore, that the antidiarrhoeal activity of S. cordatum may involve the inhibition of electrolyte permeability, prostaglandin release and nitric acid mechanism. The antidiabetic activity may be due to the plant species stimulating the release of insulin from the pancreatic beta cells since streptozotocin used to induce diabetes is known to act by rapidly depleting pancreatic beta cells and thus, reducing insulin release. Tannins and alkaloids and flavonoids may also be contributing to the antidiarrhoeal and antidiabetic activities of S. cordatum, respectively. These data may justify the use of the plant species by traditional medicine practitioners in the treatment of diarrhoea and diabetes. However, further studies on the acute toxicity, and the mechanisms of the antidiarrhoeal and antidiabetic activities of S. cordatum need to be carried out to enhance the safety and efficacy of the plant species.

\section{Acknowledgments}

The National Research Foundation, South Africa, financially supported the study (67983).The plant material was donated by Kirstenbosch National Botanical Gardens, Cape Town, South Africa. The authors wish to thank the senior academic support staff of the Discipline of Pharmacology, University of the Western Cape, Bellville, South Africa, Mr V Jeaven, for his valuable technical support. 


\section{References}

Altman, D.F., 2001. Drugs Used in Gastrointestinal Diseases. In: Basic and Clinical Pharmacology, Katzung, B.G. (Ed.). 8th Edn., McGraw-Hill, San Francisco, USA, pp: 1070-1071.

Arnabeoku, G.J. and C.G. Kinyua, 2010. Evaluation of the anticonvulsant activity of Zanthoxylum capense (Thunb.) Harv. (Rutaceae) in mice. Int J. Phannacol., 6: 844-853.

Bruneton, J., 1999. Phannacognosy, Phytochemistry, Medicinal Plants. Lavoisier Publishing, Paris.

Camillen, M., R C. Heading and W.G. Thompson, 2002. Consensus report: Clinical perspectives, mechanisms, diagnosis and management of irritable bowel syndrome. Aliment Phannacol. Ther., 16: 1407-1430.

Candy, HA, E.J. McGany, KH Pegel, 1968. Constituents of Syzygium cordatum. Phytochemistry, 7: 889-890.

Capasso, F., N. Mascolo, A.A. Izzo and T.S. Gaginella, 1994. Dissociation of castor oil induced diarrhoea and intestinal mucosal injwy in rat: Effect of NG-nitro-1arginine methyl ester. Br. J. Pharmacol., 113: 1127-1130.

Chalannavir, RK., H. Baijmth and B. Odhav, 2011. Chemical constituents of the essential oil from Syzygium cordatum (Myrtaceae). Afr. J. Biotechnol., 10: 27412745 .

Chisowa, EH., G. Sakala, DR Hall and D.I. Farman, 1998. Composition of the essential oil of Syzygium cordatum Hochst. Ex Krauss. J. Essent. Oil Res., 10: 591-592.

Di Carlo, G., N. Mascolo, AA Izzo and F. Capasso, 1994. Effect of quercetin on the gastrointestinal tract in rats and mice. Phytother. Res., 8: 42-45.

Dineshkumar, B., A Mitra and M. Mahadevappa, 2010. Antidiabetic and hypolipidemic effects of mahainmbine (carbazole alkaloid) from Murraya koenigii (Rutaceae) leaves. Int. J. Phytomed., 2: 22-30.

Farthing, M.J., 2000. Diarrhoea: A significant worldwide problem. Int J. Antimicrob. Agents, 14: 65-69.

Fawzy, GA, HM. Abdallah M.SA Marzouk, F.M Soliman and AA Sleem, 2008. Antidiabetic and antioxidant activities of major flavonoids of Cynanchum acutum L. (Asclepiadaceae) growing in Egypt Z. Naturforsch. C, 63: 658-662.

Frei, B., M Baltisberger, o. Sticher and M. Heinrich, 1998. Medical ethnobotany of the Zapotecs of the Isthmus- Sierra (Oaxaca, Mexico): Documentation and assessment of indigenous uses. J. Ethnopharmacol., 62: 149-165.

Harbome, J.B., 1984. Phytochemical Methods: A Guide to Modem Techniques of Plant Amlysis. 2nd Edn., Chapman and Hall, London, UK.

Huie, AK, AS. Shah, M.N. Gambhire and AR Juvekar, 2011. An evaluation of the antidiabetic effects of Elaeocarpus ganitrus inexperimental animals. Indian J. Pharrnacol., 43: 56-59.

Hutchings, A, 1996. Zulu Mediciml Plants: An Inventory. Natal University Press, Pietermaritzburg, South Africa, pp: 1-11. 
Ikhiri, K., D. Boureima and D. Dan-Kouloudo, 1992. Chemical screening of medicinal plants used in the traditional pharmacopoeia of Niger. Int. J. Phannacol., 30: 251-262.

Joy, K.L. and R. Kuilan, 1999. Anti-diabetic activity of Picrorrhiza kurroa extract. J. Ethrophannacol., 67: 143-148.

Kitano, Y., M. Makino, C. Usui, K. Takasuna and Y. Kasai et al., 1994. General pharmacological profile of the new cognition-enhancing agent nefiracetam. Armeirnittel-Forschung, 44: 199-210.

Lorke, D., 1983. A new approach to practical acute toxicity testing. Arch. Toxicol., 54: 275-287.

Mahomed, J.M. and JAO. Ojewole, 2003. Hypoglycemic effect of Hypoxis hemerocallidea conn (African potato) aqueous extract in rats. Methods Find. Exp. Clin. Pharmacol., 25: 617-623.

Mascolo, N., A.A. Izzo, G. Autore, F. Barbato and F. Capasso, 1994. Nitric oxide and castor oil induced diarrhoea. J. Pharrnacol. Exp. Ther., 263: 291-295.

Musabayane, C.T., N. Mahlalela, F.O. Shode and JA Ojewole, 2005. Effects of Syzigium cordatum (Hochst.) [Myrtaceae] leaf extract on plasma glucose and hepatic glycogen in strepto-zotocin-induced diabetic rats. J. Ethnopharrnacol., 97: 485-490.

Nwafor, P.A., F.K. Okwuasaba and L.G. Binda, 2000. Antidiarrhoeal and antiulcerogenic effects of methanolic extract of Asparagus pubescens root in rats. J. Ethnopharrnacol., 72: 421-427.

Punitha, L S.R, S. Arun and A Shirwaikar, 2005. Antidiabetic activity of benzyl tetra isoquinoline alkaloid berberine in streptozotocine-nicotinamide induced type 2 diabetic rats. Diabetologia Croatica, 34: 117-128.

Rang, HP., M.M. Dale, J.M. Ritter and RJ. Flowers, 2008. Pharmacology. 6th Edn., Churchill Livingstone, London, UK., pp: 402-408.

Robert, A., J.E. Neizamis, C. Lanzaster, A.J. Hanchar and M.S. Klepper, 1976. Enteropooling assay: A test for diarrhea produced by prostaglandins. Prostaglandins, 11: 809-828.

Sibandze, G.F., RL. van Zyl and S.F. van Vuuren, 2010. The antidiarrhoeal properties of Breonadia salicina, Syzygium cordatum and Ozoroa sphaerocarpa when used in combination in Swazi traditional medicine. J. EthnopharmacoL, 132: 506-511.

Tunaru, S., T.F. Althoff, RM. Nusing, M. Diener and S. Offermanns, 2012. Castor oil induces laxation and uterus contraction via ricinoleic acid activating prostaglandin EP3 receptors. Proc. Natl. Acad. Sci. USA, 109: 9179-9184.

Van Wyk, B.E., B. Van Oudtshoom and N. Gericke, 1997. Medicinal plants of South Africa. Briza Publications, Pretoria, South Africa, pp: 236-250.

Waller, D.G., AG. Renwick and K. Hillier, 2005a. Medical Pharmacology and Therapeutics. 2nd Edn., Elsevier Saunders, London, UK., pp: 417-418.

Waller, D.G., AG. Renwick and K Hillier, 2005b. Medical Pharmacology and Therapeutics. 2nd Edn., Elsevier Saunders, London, UK., pp: 457-466. 
Watt, J.M., M.G. Breyer-Brandwijk, 1962. The Medicinal and Poisonous Plants of Southern and Eastern Africa. 2nd Edn., E and S Livingstone, Edinburgh, Scotland, pp: 97-98.

Williamson, E.M., D.T. Okpako and F.J. Evans, 1996a. Pharmacological Methods in PhytotherapyResearch. Vol. I, John Wiley and Sons, Chichester, UK., ISBN: 9780471942177' pp: 25-28.

Williamson, E.M., D.T. Okpako and F.J. Evans, 1996b. Pharmacological Methods in Phytotherapy Research. Vol. I, John Wiley and Sons, Chichester, UK., pp: $155-167$.

Zavata, M.A., S. Perez, C. Perez, R. Vargos and R.M. Perez, 1998. Antidiarrhoeal activity of Waltheria americana, Commelina coelestis and Alternanthera repens. J. Ethnopharmacol., 61: 41-47. 